\title{
Universiteit
}

Leiden

The Netherlands

\section{Public discourse and community formation in a trilingual Matsigenka-Quechua-Spanish frontier community of Southern Peru}

Emlen, N.Q.

\section{Citation}

Emlen, N. Q. (2015). Public discourse and community formation in a trilingual Matsigenka-Quechua-Spanish frontier community of Southern Peru. Language In Society, 44(5), 679-703. doi:10.1017/S0047404515000597

Version: $\quad$ Publisher's Version

License: $\quad$ Licensed under Article 25fa Copyright Act/Law (Amendment Taverne)

Downloaded from: $\quad$ https://hdl.handle.net/1887/3196876

Note: To cite this publication please use the final published version (if applicable). 


\title{
Public discourse and community formation in a trilingual Matsigenka-Quechua-Spanish frontier community of Southern Peru
}

\author{
N I C H O L A S Q E M L E N \\ Leiden University Centre for Linguistics \\ Postbus 9515, NL-2300 RA, Leiden, The Netherlands \\ n.q.emlen@hum.leidenuniv.nl
}

A B S T R A C T

Until recently, the members of a community on the Andean-Amazonian agricultural frontier of Southern Peru have tended to limit their social ties to members of their own families. But the residents have begun to forge a 'community' through a semiotic distinction between private and public spaces, social practices, and domains of morality. Particular discursive phenomena in the asamblea 'community meeting' are deployed to create and maintain the community as a domain of action distinct from kin commitments, and participation in the asamblea offers a context in which to assume a novel political and moral subjectivity. Thus, the social organizational construct of the community is emergent in public interactions. The article concludes with a comparative analysis of public discourse in another comunidad nativa 'indigenous community' that has not embraced the notion of 'community', and demonstrates how code-switching allows leaders there to invoke both the private and public modes of social authority. (Amazonia, Andes, Matsigenka, Spanish, Quechua)*

\section{N T R O D U C T I O N}

In the small community of Yokiri, tucked into a remote valley among the densely forested hills connecting the Andean highlands and the Amazonian lowlands of Southern Peru, people have tended to limit their social ties to members of their own families. They live spread out across a very large area, and until recently they rarely interacted with or recognized obligations of any sort to nonkin. This highly autonomous lifestyle, known among anthropologists as 'family-level' social organization, has been common among many Matsigenka and other indigenous people of the eastern Andean slopes since the earliest records. But the expansion of the road network, the arrival of thousands of Andean agricultural migrant settlers (locally known as colonos), the adoption of commercial agriculture, and the implementation of the legal structure of the comunidad nativa 'indigenous community' have transformed the local social and economic world. One of the many 
results of these transformations is that Yokiriños (as they call themselves) have begun to establish enduring relationships with people beyond their kin groups. In particular, following the introduction of the comunidad nativa system (the legal structure through which indigenous Amazonians claim territorial rights in Peru), the people of Yokiri have come to conceive of themselves in the social organizational terms of a 'community' for the first time.

This article examines how a nascent sense of community, in which people regularly devote a portion of their time, labor, and goods to a collectivity extending beyond their own kin, has emerged in Yokiri. This reconfiguration has involved the introduction of a new domain of morality and social practice associated with the political subject of the comunero 'community member', who sacrifices private, family-level resources for the benefit of a social grouping that includes nonkin. This incipient distinction between the family and community domains of life takes the form of a private/public principle of semiotic differentiation (Irvine $\& \mathrm{Gal} 2000 ; \mathrm{Gal} 2005)$, respectively, that provides a new template for interpreting spaces, resources, periods of time and labor, and all manner of social and discursive practices.

Other researchers have addressed the social changes resulting from the introduction of the foreign comunidad nativa system among the highly autonomous indigenous people of the eastern Andean slopes of Peru (Rosengren 1987, 2003; Gray 1997; García Hierro, Hvalkof, \& Gray 1998; Veber 1998; Killick 2008). This article offers a complementary perspective on those processes by examining them as they play out at the micro level of interaction, particularly in the context of public discourse in the asamblea 'community meeting'. This monthly gathering, in which the community members come together to deliberate matters of community importance, is not simply a reflection of Yokiri's community-level social organization, but the primary site at which it is constituted. As a context for democratic political participation (modeled on other such institutions around the region and beyond), it is organized around the linguistic ideological construct of a 'public', in Habermas's (1989) sense of a forum for rational debate that is free of private and particular interests. The asamblea provides a context in which Yokiriños interact as comuneros rather than as members of kin groups (in theory if not always in practice); in this manner, the political subject of the comunero is interpellated through participation in the public arena itself (indeed, as Fred Myers and Donald Brenneis argue about such egalitarian societies, 'a political arena is an achievement, rather than a category of analysis to be taken for granted' (Myers \& Brenneis 1984:11)). In addition to its function in the explicit deliberation of community issues, public discourse in the asamblea is regimented by the language ideologies of the public and is characterized by a number of discursive phenomena that are closely connected to the enactment of a domain of social organization distinct from the family. In particular, I argue that the almost exclusive use of Spanish (instead of Matsigenka and Quechua, which predominate in other interactional contexts), the entextualization of a Spanish discourse genre I call 'official talk', the 
performance of sacrificio (the subordination of private interests to the collective good), and the disavowal of private, kin-level commitments in public interactions (for instance, through the avoidance of kin terms) are important parts of creating a public, and through it, a community. The article concludes with a comparison of Yokiri's culture of public discourse with that of a nearby comunidad nativa where community-level social organization has not taken hold, and where comиneros code-switch between Spanish and Matsigenka in public speech as a way of moving between the family and community domains of social authority.

The perspective taken in this article suggests that Yokiri's nascent culture of public discourse is a primary interactional locus for a particular set of social and political transformations underway in this corner of the Amazonian frontier. That is, beyond its broad utilitarian role in providing a structure for community administration and for mediating relationships with neighbors and the state, the public space of the asamblea offers Yokiriños a context in which to assume the novel political and moral subjectivity of the comunero. In this manner, this analysis also follows linguistic anthropological work on language shift (e.g. Gal 1979; Kulick 1992) by demonstrating how the ascendance of Spanish in Yokiri's sociolinguistic ecology (and perhaps, one day, its replacement of both Matsigenka and Quechua) is best understood not in the mechanistic terms of 'assimilation' or 'incorporation into national society', nor in the ethnographically distant idiom of 'prestige', but rather as a function of specific changes in Yokiriños' own values and aspirations as they are experienced at a day-to-day level.

\section{FROM FAMILIES TO COMMUNITIES}

Yokiri was formed by the intermarriage of a handful of Matsigenka and Andean families who migrated from a wide variety of places and circumstances across the region beginning in the 1970s. Some came from remote valleys beyond the Andean agricultural frontier, while others migrated from the nearby Dominican mission of Chirumbia, a rural area of the highland province of Paucartambo, and coffee plantations in the Yavero Valley that used enslaved Matsigenkas as laborers (for historical overviews of Matsigenkas and Andeans in the Alto Urubamba region, see Rosengren 1987, 2004, Sala i Vila 1998, A. Johnson 2003, Encinas Martín et al. 2008, and Emlen 2014). These places were sociolinguistically quite different: people who grew up beyond the agricultural frontier mostly spoke Matsigenka, while those raised in the mission at Chirumbia were also taught Spanish and learned some Quechua from their neighbors. The settlers who migrated from the highlands learned Quechua in the home as well as some Spanish in school, while for the Matsigenkas enslaved on Andean settlers' coffee plantations along the Yavero river, Matsigenka was the language of the home and Quechua was the language of work. Because these Matsigenkas were prohibited from attending school, they had little exposure to Spanish until later in their lives. The intermarriage of these diverse families in Yokiri created a sociolinguistic situation of considerable 
complexity, and most people are now trilingual. Now that the expanding road network allows for easy travel, Yokiriños are exposed to Spanish and Quechua as they visit nearby towns, and as visitors of all kinds make their way to Yokiri. Many men speak Spanish and Quechua during months-long periods of work outside of Yokiri, and several of the women spoke these languages while they lived with Andean settler men before returning to the community. Schoolchildren also learn Spanish in school, and nearly every house has a battery-operated radio that broadcasts both Spanish and Quechua programming day and night.

It is important to note here the complex role that Quechua plays in the lives of Yokiriños: while in the nearby Andean region it is a marginalized language, many Matsigenka people experience Quechua as the language of agricultural expansion and participation in the dominant capitalist economy and society (significantly, Yokiriños refer to their Quechua-speaking Andean neighbors as gente blanca 'white people', a reference to their status as colonizers rather than to their skin color). In Yokiri today, Quechua is associated with incorporation into the local agrarian world, while Spanish is the language of political life, and both Matsigenka and Quechua predominate in domestic contexts - though of course, these are ideological rather than empirical associations, and there is quite a bit of variation in practice. For a detailed sociolinguistic description of Quechua, Matsigenka, and Spanish in Yokiri, see Emlen (2014).

The families of Yokiri, who were mostly unknown to each other before the formation of the community, came together to claim the valley (one of the last uncolonized patches of land in the region) through the legal protections of the comunidades nativas law. In this manner, their legal designation as a comunidad nativa preceded their formation as a 'community' in the social organizational sense (see Killick 2008 for a similar process among Ashéninkas in Central Peru). Indeed, while kinsmen visited each other frequently, hunted together, shared meat, and aided each other in ayni 'reciprocal labor', they seldom engaged in such activities with nonkin in Yokiri-in fact, many had never even seen the houses of their nonkin neighbors, in some cases after inhabiting the same hillside for decades. This disposition toward family-level autonomy and lack of engagement with nonkin Yokiriños is reflected in Yokiri's extremely dispersed settlement pattern: in 2012, fewer than 100 people lived in nineteen houses spread out across 3,390 hectares (13.09 square miles, roughly the size of the island of Manhattan below Harlem). Until recently, Yokiriños rarely came together from their farflung homes to participate with nonkin in activities such as anniversary celebrations, faenas 'community work parties', and asambleas.

These patterns are consistent with the so-called 'family-level' of social organization that has been documented among some segments of Matsigenka society from the earliest records (A. Johnson 2003), and that are common among other indigenous groups in the eastern Andean slopes (e.g. Ashéninkas (Hvalkof \& Veber 2005; Killick 2007) and Asháninkas (Varese 2002:25)). The family-level typological classification was proposed by Julian Steward in his description of the Great 
Basin Shoshonean people: 'a family, alone and unaided, could obtain virtually all the food it consumed; manufacture all its clothing, household goods, and other articles; rear and train its children without assistance; take care of its sick except in time of crisis; be self-sufficient in its religious activities; and, except on special occasions, manage its own recreation' (1955:103). This lifestyle is well suited for subsistence in the Alto Urubamba, as well as for defense against the periodic incursions of outsiders that have ravaged the region, particularly during the nineteenth and twentieth centuries (Gade 1972; Camino 1977; Rosengren 1987; Gow 1991). In Yokiri as elsewhere, these principles of social organization have also accompanied a tendency to avoid expressions of anger and aggression (A. Johnson 1999; Izquierdo \& Johnson 2007), and to resolve disputes with nonkin by simply disengaging from conflicts and, often, moving away (O. Johnson 1978; Rosengren 2000; Rosengren 2003).

But across the Alto Urubamba region, the introduction of the comunidad nativa political structure since the mid 1970s has led many Matsigenka people to engage in sustained supra-family social commitments. Higher levels of social integration have existed among the ancestors of today's Matsigenkas ${ }^{1}$ and other people in the eastern Andean slopes at various moments (Rosengren 1987; Renard-Casevitz 1993; Killick 2007), often in response to external threats and pressures (e.g. Brown \& Fernández 1991), but in most cases these have been temporary. The comunidades nativas law, by contrast, has introduced an enduring social organizational template modeled on the nucleated peasant villages of the Andean highlands (comunidades campesinas), a structure that was foreign to many Amazonians' traditional principles of social organization (Veber 1998:394; Rosengren 2003:230; Killick 2008) (some Yokiriño families, however, had experience with such arrangements in the highlands and in the nearby Dominican mission at Chirumbia). Many of these principles are prescribed by the legal structure itself: members of comunidades nativas own their land and certain goods collectively, petition the government as a corporate body, recognize an estatuto 'bylaws' for the administration of the community and its resources, elect a presidente 'president' (also known as a jefe) and other positions of leadership, and deliberate issues of community concern in the asamblea. Community members are also required to participate in faenas, regular work parties in which all of the community's men (and sometimes its women, during a busy harvest) put aside work in their own plots and invest a full day's labor on a communal project such as repairing the road or maintaining a community agricultural plot. These new community-level responsibilities and privileges create a novel type of political subject - the comunero 'community member' - who contributes to the public good and expects the same commitment from others. The observation of these public responsibilities, which make demands of private individuals and intrude on personal autonomy, is often described in the idiom of sacrificio 'sacrifice' (discussed more below), which is regarded as an important personal virtue within the political and moral framework of the comunidad nativa. The aggregate measure of the comuneros' willingness to sacrifice their private interests for 
the benefit of the collectivity is referred to in terms of its organización 'organization', a quality that is highly valued as the foundation of political modernity, upward mobility, and national integration.

Participation in the comunidad nativa system, however, has not caught on quickly in many Matsigenka communities in the Alto Urubamba (Rosengren 1987, 2003; A. Johnson 2003). In most of the communities I visited in 20092012, only a small proportion of the residents attended asambleas, faenas, and other activities involving coordination beyond kin groups. In the communities that held regular asambleas at all, only a handful of the comuneros usually attended and participated, and most important decisions were made in private conversations rather than in the asamblea (for a similar case in Piro communities, see Gow 1991:206-11). In some communities the only attendees at community events were members of the presidente's family, suggesting that the comunidad nativa governing structure had simply been absorbed into the kinship-based system (Veber 1998:401).

But while the comunidad nativa system has not thrived in much of the Alto Urubamba, the situation in Yokiri in 2011-2012 was very different: attendance at asambleas and faenas was nearly perfect, and when a person did not turn up, comuneros from across the kin groups expressed concern for the person's wellbeing and, often, irritation at their absence. When a man failed to appear at a faena, his absence was recorded by the secretario 'secretary' and reported in the next asamblea where he was made to either justify his absence, pay a fine, or arrange to make up his day's labor in communal work (indeed, it was common to see a lone man working off his debt in the communal coffee plantation in the days after such asambleas). Yokiri's high degree of organización, which was noted with admiration by neighboring Andean settlers and the municipality's agricultural extension agents, was a point of great pride among Yokiriños concerned with the widely held stereotype of Matsigenkas as antisocial and opposed to socioeconomic development. Observing Yokiri's determined implementation of community-level social organization, one neighboring Andean man remarked to me in Spanish with surprise: jlos nativos son casi más organizados que nosotros! 'the natives are almost more organized than we are!'

THE CREATION OF A PRIVATE/PUBLIC D I S T I N C T I O N

Yokiri's notable community-level organización is accomplished through the establishment and careful maintenance of a distinction between private (family) and public (community) domains of social life. The private/public dichotomy is a principle of semiotic differentiation (Irvine \& Gal 2000) that runs through daily life in Yokiri and gives meaning to all manner of experiences and cultural practices, as described by Susan Gal: 'the ideology of public/private divides spaces, moralities, types of people, activities, and linguistic practices into opposed categories' 
(2005:24); see also Gal (2002). For instance, certain spaces in Yokiri are conceived as public (e.g. the salón comunal 'community meeting hall' and the communal coffee plantation), as defined in opposition to the private spaces of the homes and family plots. Private and public spaces are normatively associated with different regimes of morality and social commitment: discourse and work in public spaces are organized around the virtues of sacrificio and community-level organización (which are themselves connected to modernity, participation in the agricultural economy, and the Peruvian nation), while social and cultural practices in private spaces are based in obligations to kinsmen. I argue below that these spaces and domains are also connected to ideologies of language (Hill 2001:9093), in which Spanish is deemed fit for public discourse, Quechua is associated with commercial relationships on the agricultural frontier, and both Matsigenka and Quechua are used for private communication in domestic contexts (depending on the sociolinguistic background of each family). As in so many societies (e.g. Rosaldo 1974; Landes 1998), the private/public dichotomy is also a gendered distinction in Yokiri, and men tend to engage in community-level activities to a greater degree than women. For instance, men usually represent their households in the public labor of faenas while women stay home to look after the children, attend to domestic tasks, and cultivate garden crops; however, women sometimes also participate in faenas as cooks, which is considered the most domestic (i.e. private) form of public labor. In this manner, the gendered private/public distinction is subject to a fractally recursive projection (Irvine \& Gal 2000) within the domain of public labor itself (Gal 2005:26-28). The distinction between private and public spaces in Yokiri is also projected outward in the opposition between community and noncommunity: just as Yokiriños wait patiently on the trailhead rather than approach the private domestic areas of nonkin, outside visitors to Yokiri's asamblea are usually made to wait on the roadside (sometimes all day) before being invited inside to what is, by nature of their status as non-Yokiriños, a private event.

THE ASAMBLEA: CREATING COMMUNITY

THROUGH PUBLIC DISCOURSE

The asamblea takes place every month, and normally only comuneros are welcome to attend, though occasionally municipal officials, coffee merchants, schoolteachers, and neighboring settlers are invited to discuss particular issues. The primary social function of the asamblea is to institute community-level social organization through the careful differentiation of the private and public domains; indeed, the event is largely dedicated to the negotiation and policing of that boundary. This policing also goes on in other contexts such as faenas, celebrations, and countless other supra-kin interactions, and institutionalized forums such as the asamblea are not the only site of politics (Myers \& Brenneis 1984:3); however, Yokiriños understand it to be the most important and salient expression of community-hood. The asamblea is ideologically structured as a 'public', in Habermas's (1989) sense of a 
forum, equally accessible to all community members, in which 'groups of private individuals gather to discuss matters of common political concern... on the basis of reason rather than the relative status of the interactants' (Gal \& Woolard 2001:5). To be a comunero is to have - in theory - an equal stake in the determination of community policies regardless of personal characteristics such as gender, seniority, and kin-group affiliation, and to have the right and responsibility, according to Article 7 of Yokiri's bylaws, to intervenir con voz y voto 'intervene with voice and vote' (Comunidad Nativa de Yoquiri 1990) in community decisions. ${ }^{2}$

But of course, public spheres are always ideological and idealized rather than empirical constructs (Gal \& Woolard 2001:6), and in practice they can have the paradoxical effect of reproducing and institutionalizing relations of inequality (Fraser 1990). Indeed, personal characteristics can never be fully purified from the public self, and despite the ideological construction of the asamblea in terms of universal participation, not every Yokiriño has equal access to political participation. Men speak more frequently than women and occupy most of the positions of community leadership; the oldest community members who do not speak Spanish well are also at a disadvantage in the arena of public discourse, and young members are either not welcome to voice their opinions or do not feel comfortable asserting themselves among their elders. Additionally, some people who descend from Andean settlers are occasionally challenged as illegitimate participants within the context of the Amazonian comunidad nativa. As a result, despite the great amount of discursive work that goes into realizing the universalist ideology of the public, in practice the comuneros do not all have equal presence in the asamblea.

Asamblea discourse itself is a central mechanism for constituting what Warner (1992:377) calls the 'public subjectivity' of the comunero. Because the asamblea is, at its essence, a framework for engagements between nonkin community members, the very act of attending the event both presupposes and entails (Silverstein 2003) the existence of community-level social organization in Yokiri. In other words, the political subject of the comunero is interpellated through participation in the event itself (Warner 2005:77-78): consciousness of community belonging is enacted as private individuals make the long trek from their widely dispersed homes to deliberate collective concerns in the public space, as comuneros. For this reason, the often intense and acrimonious conflicts that take place in Yokiri's asamblea are not evidence of the failure of the community's public sphere, but of its success. Members of other comunidades nativas with little tradition of public participation simply do not attend such events.

The regimentation of the asamblea around the ideology of the public can be seen in the physical arrangement of the space of the salón comunal itself: the comuneros sit on low wooden-plank benches around the periphery of the room, where everyone has equal access to the floor, rather than in rows of pew-like benches facing a central podium as in other communities. People generally sit wherever they can find a space and make little attempt to segregate themselves by kin group. The egalitarian structure of the public forum also manifests in gestures toward gender equality: 
as the comuneros take their seats, the elected leaders move about the room loosely enforcing a policy of alternating male-female seating order. This is a deliberate departure from most other contexts in Yokiri in which men and women tend to gather in gender-segregated groups, and from meetings in other comunidades nativas in which men and women tend to sit apart from one another (see, for instance, Baksh 1984:417-18 and Beier 2010:384) — though, as mentioned above, the gendered disparity in participation remains significant. The elected dirigentes 'elected leaders', who usually don the green or tan municipal employee vests that serve as highly visible signs of power, authority, and access to influential outsiders, sit behind a large wooden table on one side of the room. Significantly, the salón comunal doubles as a classroom for the school —one of the primary institutions through which the community interacts with the world beyond its borders - and the walls are decorated with multiplication tables, portraits of Peruvian heroes, a large hand-written poster displaying the lyrics of the Peruvian himno nacional 'national anthem', and other signifiers of modernity and national belonging.

\section{SPANISH AS THE LANGUAGE OF PUBLIC LIFE}

The predominant language of the asamblea, and of Yokiri's public life in general, is Spanish. A representative example of public Spanish discourse in (1) comes from a speech in 2012 in which the presidente attempted to recruit his fellow comuneros to attend a meeting in the nearby settlement of Huillcapampa, so that they could entreat the municipal government to move forward with plans to build a new health post on their side of the Yavero river. As in most instances of public discourse, the presidente uses the 'official talk' discourse genre (described below) and invokes the principles of democratic participation as well as the ideology of community-level commitment.

(1) Hay que bajar también hombres y mujeres porque es necesario.. Lo iban a poner a este lado, pero los otros lo quieren al otro lado. 2 Entonces incluso quiero- cómo dice, estaba pensando tener un voto. 3 Entonces tenemos que ir todos, o sea como ya como- tenemos que bajar todos, compañeros. 4 iSomos una comunidad organizada, y tenemos que bajar y hacer sentir nuestro derecho! $!_{5}$ ¿Ya? 6 Eso sería todo, compañeros.7
'Both the men and the women have to go down [to Huillcapampa] because it's necessary. ${ }_{1}$ They were going to put [the health post] on this side [of the river], but the others want it on the other side.2 So I also want- what's it called, they're thinking of holding a vote. 3 So we all have to go, I mean since- we all have to go down there, my friends. 4 We are an organized community, and we have to go down [there] and make our rights heard! 5 Okay? ${ }_{6}$ That's all, my friends.' 7

While such public Spanish discourse is very common, the use of Matsigenka and Quechua in these contexts is rare and is usually seen as inappropriate. This division 
of linguistic practices partakes of the same ideological principle of private/public differentiation that organizes other domains of social practice in Yokiri: only Spanish is fit for community-level discourse, while Matsigenka and Quechua are generally reserved for private discourse among kin (though, as mentioned earlier, Quechua is also associated with commercial and social interactions with neighboring Andean settlers and coffee merchants). Two ideological features of Spanish qualify it as suitable for public discourse in Yokiri: first, since its arrival in the region is understood to be relatively recent ${ }^{3}$ and it is thus not associated with any subset of the community as an ethnically-marked 'mother tongue', it is seen as impartial and consistent with the participatory ideology of the Habermasian public. Second, the use of Spanish (and the 'official talk' discourse genre in particular) creates indexical associations to public political institutions across the region and beyond, and thereby asserts the type of authority exercised in those institutions. These two ideological dimensions of Spanish as a language of public discourse are discussed in turn.

Unlike Matsigenka and Quechua, which are associated with either side of a deep historical conflict between indigenous Matsigenka people and Andean settlers (the history, of course, is far more complex than this dichotomy suggests - these are local ideological formulations rather than empirically delimitable 'groups'), Spanish is understood to be a new feature of the linguistic landscape and, consequently, unconnected to claims of historically rooted ethnic affiliation. While in the Andes Spanish is associated with centuries of violence and oppression (e.g. Mannheim 1998), Yokiriños have a longer and more intimate historical experience of domination by Quechua speakers. It is this (relative) freedom from partial and exclusionary associations that makes Spanish fit for public discourse in a community that conceives of itself as multi-ethnic: because Spanish is noone's, it can be everyone's. This is an important element of the ideological construct of the public, in which rational and transparent debate must be conducted in a neutral and universally accessible language lest private and partial interests jeopardize its integrity. Such ideologies of language are common, for instance, among some English-speaking voters in California in the 1980s who feared that Spanish-English bilingual ballots would introduce divisive partiality into what is meant to be an open and transparent democratic process (Woolard 1989). Similarly, national standardization movements often seek to institutionalize a public language that is seen as ethnically unmarked or 'unnative' (Errington 2000:206), and thus ostensibly disinterested and free from private, partial, ethnic, or regional commitments - that is, these languages can serve the purposes of national integration insofar as they belong to 'everyonebecause-noone-in-particular' (Gal 2001:33; see also Warner 1990).

Yokiri's Spanish-only culture of public speech is different from that of the neighboring Andean settler communities, where everyone speaks and understands Quechua, and where some of the older residents do not speak much Spanish. In these communities, Quechua and Spanish are acceptable in public speech because they both serve the function of (near-)universal accessibility and because neither language is associated with a particular ethnically marked subset of 
the community. For this reason, speeches given in Quechua and Spanish in the nearby Andean settlement of Estrella during the visit of the municipal authorities in 2012 were considered perfectly acceptable - for instance, in (2) a man codeswitched between Spanish and Quechua discourse in a plea for a road (Quechua discourse is underlined).

(2) Señor alcalde, Señores regidores, compañeros, muy buenos días. 1 Wakin compañeruykuna comentanku, manan kanchu carretera.2 Manan kan- o sea, ruta, a veces vienen comentarios, ¿no $?_{3}$ Anchayta munayku, Señor alcalde...4
'Mr. Mayor, Mrs. council members, my friends [i.e. other community members], good morning. 1 Some of my friends have commented, there's no road.2 There's no- I mean, sometimes people comment, no? 3 That's what we want, Mr. Mayor...' 4

But while this use of Quechua public speech was acceptable and unremarkable in neighboring Andean settler communities, in Yokiri it would have been considered a provocative transgression of the community's public discursive space, regardless of the fact that most Yokiriños understand Quechua. Such incidents are not unknown in Yokiri, however: tensions mounted in one asamblea when a comunero with close ties to the rural agrarian society and economy asserted his superior knowledge of agriculture by embedding a brief Quechua statement about cash cropping in a larger exhortative speech in Spanish. This was offensive for two reasons: first, not all of the comuneros understand Quechua well, so it violated the public accessibility requirement. Second, the man's use of Quechua laid bare an uncomfortable truth about Yokiri: while Quechua is widely spoken among the comuneros, it is also associated with an invasive economic and social system that Yokiriños regard with great ambivalence. And insofar as the comunidad nativa system was established to protect indigenous Amazonians from the encroachment of Andean settlers, the presence of Quechua in Yokiri-and particularly in the asamblea, the heart of the community's political identity - is a reminder of the painful recent history of Andean colonization. By contrast, the use of Matsigenka also violates the asamblea's principle of universal participation, since some Yokiriñosparticularly those from the highlands of Paucartambo, the coffee plantations of the Yavero Valley, and the nearby Dominican mission - do not understand Matsigenka as well as the others. Thus, even though the community is ideologically and legally constructed around the ethnic category of 'Matsigenka', competence in the Matsigenka language is too thinly distributed for it to serve the Habermasian function of universally accessible public discourse in the asamblea. The transgression of this boundary, however, can also serve a potent strategic function: if the use of Quechua in the public space of the asamblea represents a challenge to Yokiri's legitimacy as an indigenous Amazonian community, the use of Matsigenka can assert Matsigenka ethnicity as a necessary criterion of belonging (and thus implicitly 
challenge the legitimacy of comuneros who count Andean settlers among their parents and grandparents). These complexities in Yokiri's ideologies of public discourse are the product of the community's particular history, and are therefore different from those of both the neighboring Andean settlements and other Matsigenka communities across the region (such as the one discussed below).

In addition to its ideological construction as a neutral, nonpartisan language, Spanish - in particular the register of 'official Spanish' that is closely connected to the discourse genre of 'official talk' - also serves the functions of public asamblea discourse through its association with such discursive contexts outside of Yokiri. Meetings across the country, from the neighboring Andean settler communities to the floor of the Peruvian Congress, are conducted in the genre of official talk, and Yokiriños entextualize it in order to invoke and assert the mode of authority exercised in such contexts (Briggs \& Bauman 1992). This effect is heightened by the community leaders' municipal employee vests and the countless other signifiers of officialdom and Peruvian-ness draping the schoolroom walls, which serve to minimize the indexical distance (Briggs \& Bauman 1992) between the asamblea and the widely recognized 'official public meeting' event-type (Silverstein 2005). The institutionalization of Spanish as the language of democratic debate and bureaucratic procedure is taken further by its codification in the community's bylaws, according to which 'every act must be recorded IN SPANISH in an authorized notebook, [and] the president, the secretary of the communal assembly, and no fewer than five other people must sign the acts' (Comunidad Nativa de Yoquiri 1990:6, translation mine, emphasis added) - a textual regime that, in Hill's words, 'index[es] rationality over emotional commitment' (2001:91). In these ways, the use of the official Spanish register and the invocation of the official talk genre help establish the community public by creating interdiscursive links between Yokiri's asamblea and other such institutions across Peru.

Official talk is a particularly monologic discourse genre, normally performed while standing, in which a single speaker holds the floor for a period that can range from less than a minute to more than twenty minutes. Speakers usually begin their speech with an opening formula in which they acknowledge their fellow comuneros, and in some cases the presidente and other members of the directors' council, as addressees. When prominent noncommunity members visit Yokiri, speakers often explicitly recognize them as well. A typical example of such an opening formula, given in (3), comes from a 2011 asamblea in which a woman rose to give a report on her recent trip to the education ministry (such opening formulas can also be seen in transcripts (7), (8), and (11) below). Notably, this speaker is the presidente's mother, but she refers to her son here as Señor jefe de la comunidad 'Mr. president of the community', a common strategy for downplaying private kin associations (discussed below).

(3) Ante todos, compañeros, comuneros y comuneras, Señor jefe de la comunidad, tengan muy buenos días. 
'Before all of you, my friends, [male and female] community members, Mr. president of the community, good morning.'

The speeches are normally brief and succinct, and are addressed to the asamblea as a group rather than to specific individuals (what Warner (1992:378) calls 'impersonal reference', a central feature of public discourse). Most speeches end with a statement of conclusion or thanks, as in eso sería todo, compañeros 'that is all, my friends' in (1) above, and in one woman's closing of a 2011 speech in (4) below (other examples can be found at the end of transcripts (7) and (11)). Some of these speeches are followed by light applause.

(4) Esa sería mi palabra, muchas gracias a todos.

'That's my word [i.e. message], thank you very much to everyone.'

With few exceptions, official talk in Yokiri is conducted in Spanish, with virtually no code-switching in Matsigenka or Quechua (Yokiri is unlike other Matsigenka communities in this respect, as I discuss below). The 'official Spanish' register is immediately recognizable by people across the region and includes features and constructions not normally used in other interactional contexts, such as the indirect first person construction mi persona 'my person', for example, éste es un regalo de mi persona para la comunidad 'this is a gift from me (lit. 'from my person') for the community'. Public speeches also often feature the address term compañeros (as can be seen in transcripts (1), (2), (3), (7), and (8)), which can be glossed as 'my friends' or 'my companions', and which invokes a sense of egalitarian solidarity with other comuneros. Speakers also maintain their audience's attention by punctuating their speech with brief interrogative constructions, which add a sense of dialogism into otherwise overwhelmingly monologic stretches of discourse. These consist of questions that the speaker poses and then immediately answers (as in (5), excerpted from transcript (7) below), or simply ¿no? 'no?' or ¿no es así? 'isn't that right?' (as in both (5) and (6), excerpted from transcript (8) below).

(5) Tal vez no lo hemos hecho hasta hoy, ¿no? ¿Por qué? Por los motivos de que siempre hemos estado pues en dificultades...

'Perhaps we haven't done it until today, no? Why? Because we have always had difficulties...'

(6) Como me estoy escuchando todo cómo se llama este los que están presentes¿no?- ya creo que ya [ha puesto] un torete, ¿no?

'Since I've been listening to everyone present- no?- I think someone [pledged] a bull, no?'

As discussed above, the use such features of Spanish official talk positions the asamblea in the context of other public forums across Peru. It is therefore worth pointing out the most salient local model of the genre, which is produced by the 
municipal officials and functionaries that visit Yokiri periodically, and who are the immediate exemplars of the sort of democratic political modernity enacted in asambleas. For instance, in 2012 a local regidor 'councilman' stood and gave a long speech during the laying of the first stone for Yokiri's new municipally funded salón comunal (excerpted in (7)), and deployed many of the features described above (monologic participant structure, opening and closing formulas, frequent use of the address term compañeros, and brief interrogative constructions that introduce a sense of dialogism) in the service of modern political themes such as infrastructure development and engagement between the community and the local government.

(7) Bien, este, compañero regidor, ingeniero jefe del obra, el arquitecto Alex, al jefe de personal que nos ha acompañado hoy día- ¿no?- Mario.. 1 Y compañeros de esta comunidad de Yokiri. ${ }_{2}$ En verdad para mí es realmente un día significativo- ¿no?- estar junto a Ustedes.3 Tal vez no lo hemos hecho hasta hoy, ¿no? $?_{4}$ ¿Por qué? ${ }_{5}$ Por los motivos de que siempre hemos estado pues en dificultades...6

... Bien compañeros, con todo esto dicho, yo pues agradezco por escucharme, y también felicitarles¿no?- a todos Ustedes por estar hoy día.7 Muchas gracias.8
'Okay, um, my friend the councilman, the engineer, leader of the project, the architect Alex, [and] the team leader who has accompanied us today- no?Mario. 1 And my friends in this community of Yokiri.2 Truly, for me this is a really significant day- no?being together with you. 3 Perhaps we haven't done it until today, no? Why? ${ }_{5}$ Because we have always had difficulties...' 6

'... Okay my friends, with all of this said, I thank [you] for listening to me, and [I] also congratulate you- no?- to all of you for being [here] today. ${ }_{7}$ Thank you very much.' 8

Such instances of Spanish official talk by influential and politically modern outsiders represent important prototypes for public speech in Yokiri.

\section{PERFORMING $S A C R I F I C I O$ AND POLICING THE P R I VATE/P U B L I C B O UND A R Y}

As a practical matter, the primary social function of the asamblea is to coordinate community action and mediate relationships among members of different kin groups (e.g. the planning of faenas, the organization of community celebrations, decisions about the community's stance toward outsiders, the distribution of public goods, etc.). Nearly all such concerns are organized around enforcing each family's commitment to the collectivity (i.e. the fulfillment of their duties as comuneros) and ensuring that each family benefits equally from community membership. 
The asamblea, then, can be seen as an extended litigation of the boundary between the private (kin) and the public (community) domains, and in particular as a context for enacting and monitoring the form of morality expressed by the virtue of sacrificio described above. Indeed, the performance of sacrificio, in which comuneros recount the hardships they have endured on behalf of the community, is a major discursive theme in the asamblea. An example of such a performance is a speech delivered by a woman who had been appointed as the community's radio operator because of the proximity of her home to the antenna, and who listens to the transmissions and takes messages every morning and evening. In 2011 she stood before the asamblea and described the great burden this public responsibility put on her-but, crucially, that she had borne this sacrificio without complaint or expectation of anything in return. This sort of unhesitating generosity is understood as a virtuous act within the moral context of community social organization, and such proclamations are frequently deployed (as in this case) to insinuate an opposing kin group's dereliction in their own communal responsibilities. Dirigentes also frequently recount their sacrificios in the idiom of sufrimiento 'suffering'-for instance, in the presidente's statement during an asamblea, yo he sufrido mucho por esta comunidad 'I have suffered greatly for this community'. These performances of sacrificio and sufrimiento invoke the moral ideologies of public action and serve an important role in building commitment to the collectivity.

The most spectacular performance of sacrificio I witnessed in Yokiri was during the planning of the festivities for the community's patron saint, Santa Rosa of Lima. The comuneros contribute material supplies for such events, and the two major kin groups of Yokiri use them as an opportunity to out-do each other with lavish acts of public sacrifice. In this asamblea, in which a few municipal officials were present, members of each household stood and publicly stated what they would contribute to the next year's celebrations. Hernán, a prominent member of one of the two main kin groups, keyed the genre of official talk by beginning with an opening formula as discussed above, and by using features such as the honorific second person forms. In (8) he pledged to donate a bull to be slaughtered for the next year's celebration, and used his act of selflessness to accuse the opposing kin group, as well as the municipal official, of stinginess.

(8) Secretary:

Procediendo el compromiso, vamos a ceder los micrófonos al compañero Hernán. 1 [passes microphone to Hernán]

Hernán: [inaudible, joking confidently with his kin, laughing] Bueno, este, compañeros, este [inaudible] de Santa Rosita este lo que están aquí tengan todos
'Moving along with the pledges, let's yield the microphone to our friend Hernán' ${ }_{1}$ [passes microphone to Hernán] [inaudible, joking confidently with his kin, laughing] 'Well, my friends, the [attendees] to [the festival] of Santa Rosita de Lima that are here, good afternoon to 


\author{
muy buenas tardes.2 Yo como \\ mi voto de Sta. Rosita de Lima, \\ yo- como me estoy escuchando \\ todo cómo se llama este los que \\ están presentes- ¿no?- ya creo \\ que ya [ha puesto] un torete, \\ ¿no $?_{3} \mathrm{Y}$ a mi, [inaudible] no me \\ quedo atrás compañeros, y yo \\ también voy a hacer, cómo se \\ llama, voy a, cómo se llama, ya \\ estoy- o sea que todos se \\ achican- ¿no?- a pesar que \\ tienen plata a pesar que aquél \\ cómo se llama mi amigo \\ Hernán Díaz, ¿no? ${ }_{4}$ A pesar que \\ trabaje en municipio se ha \\ achicado, ¿no? $?_{5}$ Pero yo no voy \\ a achicar, iyo voy a poner un \\ torete! 6 \\ Community: ¡Bravo! 7 [loud applause]
}

all of you.2 I, as my pledge to Santa Rosita de Lima, I- since I've been listening to everyone present- no?- I think someone [pledged] a bull, no ${ }_{3}$ And me, [inaudible] I'm not going to be left behind, my friends, and I'm also going to make, what's it called, I'm going to, what's it called, I'm- I mean, everyone has been stingy- no?- even if they have money, even though he, what's his name, my friend [the municipal official] Hernán Díaz, no? ${ }_{4}$ Even though he works for the municipality, he is stingy, no? ${ }_{5}$ But I'm not going to be stingy, I'm going to contribute a bull!' 6

'Bravo!' 7 [loud applause]

The contribution of a bull, which can cost more than 1,000 soles (around $\$ 350$ dollars at the time), is a major act in Yokiri. The speaker's dramatic display of sacrificio, and his defiant and confrontational tone, positioned him and his kin group as a dominant force in the community and as an exemplar of virtue in the moral context of the community public.

NO TENGO NI MAMÁ NI PAPÁ: THE S UPPRESSION OF KIN ALLEGIANCES

If the moral space of the asamblea is organized around the subordination of private interests to those of the community, the expression of kin allegiances in that context can be hazardous. For this reason, another major theme in the asamblea is performing the separateness of family and community commitments. However, one of the fundamental structural tensions within the tiny community of Yokiri is that the presidente and the other dirigentes - the people responsible for enforcing the prioritization of community action over kin-based allegiances-are themselves members of kin groups with their own interests and agendas. The leaders are keenly aware of the danger that this poses to their legitimacy, and they make great efforts to avoid the appearance of impropriety by foregrounding the separateness of their public and private commitments. This is accomplished through innumerable acts of semiotic differentiation, including the use of Spanish official talk to assert the kin-neutral nature of the asamblea and the discursive disavowal of kin 
commitments. For example, while in most contexts Yokiriños refer to their kinsmen almost exclusively with kin terms, in the asamblea they use the same honorific constructions that they use for nonkin (such as example (3) above, in which a woman addressed to her son, the president of the community, as Señor jefe de la comunidad 'Mr. president of the community'). On another occasion (see (9)), the presidente listed the names of several community members, and only used the honorific title Señor 'Mr.' for his own father, Aníbal.

(9) ...cuarto, Julián; quinto, Santiago; como sexto tenemos al Señor Aníbal; séptimo Mario...

'...fourth, Julián; fifth, Santiago; as the sixth we have Mr. Aníbal; seventh, Mario...'

These practices of semiotic differentiation entail a public populated by comuneros rather than kinsmen, and reassure members of the other kin groups that the elected officials can be trusted to act in the interest of the collectivity rather than their families.

An example of the delicate negotiation of kin and community commitments was a conflict between Yokiri's two major kin groups that developed in 2012. The foreman of a municipal construction crew working in Yokiri needed a cook for his workers, and prominent women from each of the two major kin groups declared their interest in being hired. It fell to the asamblea and the presidente to choose which of the women would get the prestigious and remunerative job; however, one of the nominees was the presidente's kin, which presented a clear conflict of interest. This dispute went unresolved for several days, slowly building into a wider conflict over other perceived violations of private/public boundary, until it finally came to a head in a fistfight (almost unheard of in Matsigenka communities) between the husbands of the two women. This rare outburst of violence precipitated an unusually frank public discussion about the management of private and public commitments. During the meeting the presidente made a long and emotional plea on behalf of community organización, and after delivering a withering (and studiously equal-handed) reproof to both parties, he reaffirmed the boundary between private and public spheres by promising to leave his own kin-level commitments out of community matters. In his words: en la asamblea, no tengo ni mamá ni papá 'in the asamblea, I have neither a mother nor a father' - that is, in the public space of the community forum, there are no kinsmen, only comuneros.

YOKIRI'S PUBLIC DISCOURSE IN

COMPAR ATIVE PER S PECTIVE

The role of public discourse in Yokiri's enactment of community-level social organization becomes particularly clear when it is compared with corresponding practices in other comunidades nativas of the Alto Urubamba. The example that follows 
comes from a larger and more remote community that has just begun to interact regularly with outsiders over the last several years. Here, the public/private semiotic principle has not been firmly established as a framework for sorting the domains of community and family commitments, for dividing spaces and sociolinguistic practices, and for enforcing the new type of morality - characterized by sacrificio and the suppression of kin allegiances - associated with the public political subject of the comunero.

For the community's 2011 anniversary, the dirigentes planned an ambitious multi-day celebration featuring a soccer tournament, speeches, drinking, feasting, and dancing. Municipal officials and other local dignitaries were invited, and the comuneros were expected to bring masato 'manioc beer' for the guests and carry on the merriment for as long as they could last. The celebrations appeared to be successful during the first afternoon, but when the party turned indoors for speeches, dancing, and the distribution of soccer jerseys, the crowd began to thin. The remaining comuneros sat with their kin and talked among themselves in Matsigenka instead of listening to the speeches, and the dirigentes had to shout over the din to make themselves heard. Eventually, once the jerseys had been distributed, the remaining comuneros began to file out of the salón comunal and walk home. This was embarrassing for the dirigentes, and the presidente in particular, because it suggested that the community lacked organización and effective leadership. As the comuneros rose to leave, a panicked leader shouted the plaintive appeal in (10a-b) (Spanish in plain text, Matsigenka underlined).

(10) a. Señores comuneros por favor, gara piaigai, tera ontsonkatempa, por favor...

'Fellow community members please, don't leave, it's not over [yet], please...'

b. Suplico a cada uno de ustedes, quedan invitados para poder iniciar este aniversario que concierne con nuestro $[\mathrm{X}]$ años de vida institucional.

'I beg each of you, you are invited so that we can begin this anniversary for our $[\mathrm{X}]$ years of institutional life.'

This plea for participation illustrates the fragile nature of the community, as well as some of the discursive strategies that leaders deploy in its defense. For instance, the speaker explicitly invoked the moral domain of the community public by addressing the attendees as comuneros (10a) and by referring repeatedly to the institutional structure that unites them. He also framed his discourse as public by deploying Spanish official talk, as indicated by the opening formula señores comuneros, por favor ... 'fellow community members, please...' (10a). Recognizing that his addressees were likely to be unmoved by these entreaties to community participation, however, he switched to Matsigenka to make a personal and intimate appeal outside of the frame of public discourse: gara piaigai, tera ontsonkatempa 'don't 
leave, it's not over [yet]' (10a). In this utterance, code-switching served as a contextualization cue (Gumperz 1982) signaling the alteration between two 'voices' (Bakhtin 1981), each connected to distinct ideologies and moral regimes (Hill 1995); through Spanish, he inhabited the position of the official leader whose authority lies in a powerful but foreign system of public value, while through Matsigenka, he stepped outside of this position to speak as a kinsman, friend, and neighbor who, along with his audience, also regards this system from the outside.

Such discursive practices are common in this community, and many dirigentes code-switch between Spanish and Matsigenka to assert both modes of authority. For instance, during the same evening a few current and former dirigentes delivered speeches to the remaining comuneros. They were frustrated and embarrassed by what they saw as the failure of the event, and some used their speeches to admonish their fellow comuneros and exhort them to take community involvement more seriously. To make this point, a former leader recounted the difficulties of the land titling process to illustrate the sacrificio and sufrimiento that he had endured on behalf of the community (see (11)). As in (10a-b) above, this speech is characterized by frequent Spanish-Matsigenka code-switching as the speaker moves between the two modes of social authority (Spanish in plain type, Matsigenka underlined).

(11) Eh, buenas noches señores, señores directivos y todos, muy buenas noches, ¿no $?_{1} \ldots$ En el año $[\mathrm{X}]$ sale el título de propiedad de [community name].2 Ovashi otimanunganira aka.3 De repente viroegi yoga ikyari kimoiganagitsi te pineaigena.4 Naroegi nantavageigake maani aunque no será mucho.5 Maika nanuventakero ashi comunidad, a lo menos debemos felicitar a [name], que ha luchado bastante, iniaventakera ashi comunidad ompeganakempara ontimakera ampatoitakempara agaigakerora gipatsiegite. 6 Ganiri yagapitsahaigiro yoga virakocha.7 ... Oga otimakera maika como día como veinticuatro nokogavetake irinake presidente de la comunidad [inaudible] y con toda la nueva junta directiva nonei aryori maika shineventaigakemparo shatekaigakempara aka maganiro todos los comuneros, pogavoaigakera sekatsi ashi shitea.8 Sin embargo noneavetaro maika ontirika pikisaigaka
'Um, good evening sirs, directors, and everyone, very good evening, no ${ }_{1} \ldots$ In the year $[\mathrm{X}]$ we got the property title for the community of [community name $]_{2}$ That's why it's here. 3 Perhaps you young ones don't know who I am.4 We [exclusive] did some work, even if it wasn't much. 5 We traveled [to complete the titling] for the community, at least we should congratulate [name], who has fought a lot, he has conversed [i.e. made the official arrangements] so that the community would become, so that there would be, so that we could get together and get our land. 6 So that the colonists don't take it away. ${ }^{7}$... Now on a day like the twenty-fourth, I wanted the president of the community [inaudible] to be here with all of the new directors' council, and I thought that we were going to celebrate it, and that [the building] would be full of all the community members, [and] that 
onti kisaigankicha yonta tera impokaige ahorita.9 Pairatake mameri. ${ }_{10}$ Kantaka ontinirika tata oita yovetsikaiganake, noneakero naro tera onkametite. ${ }_{11}$ Estoy triste. 12 Lamentablemente la nueva junta directiva ikogaigavetaka irovetsikakerora kameti, pero tyani kañoigankitsi? 13 Viroegita kañoigankitsi, comuneros. 14 Tenika patsipereigero viro pero sí naroegi natsipereaventaigakero para que salga la titulación oka de siete mil hectareas y otra titulación de la ampliación. 15 Nashi novetsikaigakerira naroegi

nantaigavetakarira, viroegi jovenes te pogogeeronika- viro pineirokari okavagetaka kogapage. 16 Pisureiganaka pogutera shitea, y ¡no! Noneakero naro te onkametite. 17 Antari maika

sureigakemparomera es una celebración conmemorativo patoigakempara maganiro ariangi gaveakoigakerora nuestra comunidad otimakera. ${ }_{18}$ Hemos tenido título, game otimi título, tya gaigakero timaigakera? 19 Matsi ari timake karaseigake inkisaigapakae inti virakocha. 20 Eso sería mi única recomendación, gracias. 21 they would bring yuca for masato. 8 Regardless, from my perspective it seems that the ones who didn't come now are annoyed and angry. 9 Nobody is here. 10 It seems that they're doing something wrong, from my point of view that's not good. ${ }_{11}$ I am sad.12 Unfortunately the new directors' council wanted to have a good [celebration], but who are the guilty ones? 13 You are the guilty ones, comuneros. 14 You haven't suffered, but we [exclusive] have suffered in order to obtain the title, um, to seven thousand hectares and the other title to the territorial extension. 15 What we did during our tenure, what we were doing, you young people don't know- you must think it was easy.16 You thought about bringing masato, but no! From my point of view it's not good. 17 We would have thought that since it's a commemorative celebration, everyone would have come together, for the effort and the achievement to make our community exist. 18 We got the title, [because] if there weren't a title, where would we find to live? 19 If we hadn't lived and made our chacras here, the colonists would have kicked us out.20 That's my only recommendation, thank you.' 21

In this emotional speech, the former dirigente blamed the assembled community members for the disappointing anniversary celebration (e.g. sentence 14, viroegita kañoigankitsi, comuneros 'you are the guilty ones, comuneros'), a failure that he interpreted in terms of a disrespect for the community as an institution and a general unwillingness to meet the moral obligations of the comunero. The speaker relates this message through the careful management of voice and authority, in particular through his code-switching practices. First, he invokes the public authority of the community by framing his remarks as a performance of public official talk, as in the opening (sentence 1) and closing (sentence 21) formulas described above. He also uses Spanish to highlight concepts linked to the comunidad nativa social structure, for instance es una celebración conmemorativo [sic] 'it's a 
commemorative celebration' (sentence 18) and hemos tenido título 'we got the title' (sentence 19). The speech also makes frequent references to sufrimiento and sacrificio (e.g. tenika patsipereigero viro pero sí naroegi natsipereaventaigakero 'you haven't suffered, but we [exclusive] have suffered...', sentence 15) that invoke the morality of the community public.

As above, the speaker frequently switches between Matsigenka and Spanish to maintain a foot in both domains of authority. For instance, in some cases he frames his utterances as official talk through the use of Spanish discourse markers, and then continues his utterance in Matsigenka to appeal to his audience in a more personal manner. For instance, in (12) (from sentence 4) he established his utterance as official talk with a loud Spanish de repente 'perhaps', followed by Matsigenka discourse.

(12) De repente viroegi yoga ikyari kimoiganagitsi te pineaigena.

'Perhaps you young ones don't know who I am.'

Similarly, in (13) (from sentence 9) the speaker keyed the frame of official talk by shouting the Spanish discourse marker sin embargo 'regardless, nevertheless' over the din before making a personal and emotional appeal to his audience in Matsigenka.

(13) Sin embargo, noneavetaro maika ontirika pikisaigaka onti kisaigankicha yonta tera impokaige ahorita.

'Regardless, from my perspective it seems that you're angry, and the ones who are angry didn't come now.'

A similar discursive strategy is the pairing of a Spanish utterance that reconfirms the speaker's position of official authority with a Matsigenka utterance that aligns the speaker with his audience. For instance, in both (14a-b) (sentences 2-3) and (15) (sentence 19) the speaker assumes the official voice to introduce the subject of land titling, and then uses Matsigenka to reflect upon the importance of that subject from the perspective of his kinsmen and fellow comuneros in the audience.

(14) a. En el año [X] sale el titulo de propiedad de [community name]. 'In the year $[\mathrm{X}]$ we got the property title for the community of [community name].'

b. Ovashi otimanunganira aka. 'That's why it's here.'

(15) Hemos tenido título, game otimi título, tya gaigakero timaigakera?

'We got the title, and if there weren't a title, where would we find to live?' 
This discursive strategy allows the leader to assert the legitimacy of the comunidad nativa's fragile community structure while also aligning himself with an audience that is not yet fully committed to it. In a sense, he must come as close as possible to speaking both languages at once if he is to maintain a foot in each domain of authority. In Yokiri, community-level social organization is now taken for granted and the distinction between private and public social, moral, and discursive spaces has been carefully delineated - for this reason, code-switching is rare there. But in this community, public code-switching practices are tied to the incipient nature of the private/public boundary and the still contested nature of collective commitment.

\section{O N C L U S I O N}

In the Alto Urubamba and other regions of Peruvian Amazonia, the legal structure of the comunidad nativa has existed for nearly forty years. The principles of community-level social organization that it prescribes are quite foreign to the Matsigenkas' traditional dispersed and atomistic kinship-based pattern; however, at this point the majority of the residents of many communities were born after their introduction, and have begun to embrace them. In Yokiri, the creation of a community from a handful of dispersed families has been achieved by cleaving off a new domain of community life from the social world of the kin group, through the introduction of a semiotic distinction between public and private commitments. The creation of the public political subject of the comunero - defined in opposition to the family member and morally obligated to people beyond the private world of kin relations - is created and maintained in myriad social and discursive practices. For Yokiriños, the most important of these is the Habermasian forum of the asamblea, where public subjectivity is created and enacted through discursive features such as the near exclusive use of Spanish, the use of the 'official talk' discourse genre, the performance of sacrificio 'sacrifice' (the subordination of private commitments to collective interests), and the disavowal of family commitments through, among other practices, the avoidance of kin terms. While other studies have examined the social, political, ecological, and historical dimensions of the adoption of the comunidad nativa system in Peruvian Amazonia, the discursive and linguistic features of this process as it is enacted and negotiated at the micro level of interaction are also important for understanding how this new framework of social organization is taking hold.

\section{N O TES}

\footnotetext{
*Thanks to La Comunidad Nativa de Yoquiri, El Consejo Machiguenga del Río Urubamba, Bruce Mannheim, Barbra Meek, Lev Michael, Jane Lynch, Vanessa Díaz, Elana Resnick, Julia Emlen, and the reviewers and editors of Language in Society. This research was supported by a Fulbright-Hays Doctoral Dissertation Research Abroad (DDRA) Fellowship and NSF Doctoral Dissertation Improvement Grant No. 1021842. Any opinions, findings, and conclusions or recommendations expressed in this
} 


\section{PUBLIC DISCOURSE AND COMMUNITY FORMATION}

material are those of the author and do not necessarily reflect the views of the National Science Foundation. The research leading to these results also received funding from the European Research Council under the European Union's Seventh Framework Programme (FP7/2007-2013)/ERC grant agreement n 295918.

${ }^{1}$ Note that the notion of 'Matsigenka' as an ethnic group is a recent innovation: the ethnonym was first used by Dominican missionaries in the late nineteenth century to refer to the Indians in their newly formed prefecture, and it was not taken up by Matsigenka speakers themselves until the 1960s (Rosengren 1987:37, 2004:11-12). For this reason, I avoid using the term in discussions of prior historical periods.

${ }^{2}$ Just as the Constitution of the United States is constructed as both authored by and addressed to a depersonalized American public 'we' (Warner 1990:111-12), Yokiri's estatuto 'bylaws' is conceived as both issuing from the community's collective will and mandating a framework for its proper execution.

${ }^{3}$ In fact, Matsigenka, Quechua, and Spanish have been spoken by various people in the region for centuries.

\section{REFERENCES}

Bakhtin, Mikhail M. (1981). Discourse in the novel. In Mikhail M. Bakhtin (ed.), The dialogic imagination, 259-75. Austin: University of Texas Press.

Baksh, Michael (1984). Cultural ecology and change of the Machiguenga Indians of the Peruvian Amazon. Los Angeles: University of California, Los Angeles dissertation.

Beier, Christine (2010). The social life and sound patterns of Nanti ways of speaking. Austin: University of Texas, Austin dissertation.

Briggs, Charles, \& Richard Bauman (1992). Genre, intertextuality, and social power. Journal of Linguistic Anthropology 2:131-72.

Brown, Michael F., \& Eduardo Fernández (1991). War of shadows: The struggle for utopia in the Peruvian Amazon. Berkeley: University of California Press.

Camino, Alejandro (1977). Trueque, correrías e intercambios entre los Quechuas Andinos y los Piro y Machiguenga de la Montaña Peruana. Amazonía Peruana 1:123-40.

Comunidad Nativa de Yoquiri (1990). Estatuto de la Comunidad Nativa de Yoquiri.

Emlen, Nicholas Q. (2014). Language and coffee in a trilingual Matsigenka-Quechua-Spanish frontier community on the Andean-Amazonian borderland of Southern Peru. Ann Arbor: University of Michigan dissertation.

Encinas Martín, Alfredo; Ángel Perez Casado; \& Rafael Alonso Ordieres (2008). Historia de la Provincia de La Convención, Tomo II: Historia social y religiosa del siglo XX. Lima: Centro Cultural José Pío Aza.

Errington, J. Joseph (2000). Indonesian('s) authority. In Paul V. Kroskrity (ed.), Regimes of language, 205-27. Santa Fe, NM: School of American Research Press.

Fraser, Nancy (1990). Rethinking the public sphere: A contribution to the critique of actually existing democracy. Social Text 25/26:56-80.

Gade, Daniel W. (1972). Comercio y colonización en la zona de contacto entre la sierra y las tierras bajas del Valle del Urubamba en el Perú. Actas y Memorias del XXXIX Congreso Internacional de Americanistas 4:207-21.

Gal, Susan (1979). Language shift: Social determinants of linguistic change in bilingual Austria. New York: Academic Press.

(2001). Linguistic theories and national images in nineteenth-century Hungary. In Susan Gal \& Kathryn A. Woolard (eds.), Languages and publics: The making of authority, 30-45. Manchester: St. Jerome.

(2002). A semiotics of the public/private distinction. Differences 13:77-95.

(2005). Language ideologies compared: Metaphors of public/private. Journal of Linguistic Anthropology 15:23-37. 
\& Kathryn A. Woolard (2001). Constructing languages and publics: Authority and representation. In Susan Gal \& Kathryn A. Woolard (eds.), Languages and publics: The making of authority, 1-12. Manchester: St. Jerome.

García Hierro, Pedro; Søren Hvalkof; \& Andrew Gray (1998). Liberation through land rights in the Peruvian Amazon. Document 90. Copenhagen: IWGIA.

Gow, Peter (1991). Ofmixed blood: Kinship and history in Peruvian Amazonia. (Oxford studies in social and cultural anthropology.) Oxford: Oxford University Press.

Gray, Andrew (1997). Indigenous rights and development: Self-determination in an Amazonian community. Oxford: Berghahn Books.

Gumperz, John J. (1982). Discourse strategies. Cambridge: Cambridge University Press.

Habermas, Jürgen (1989). The structural transformation of the public sphere: An inquiry into a category of bourgeois society. Cambridge, MA: MIT Press.

Hill, Jane H. (1995). The voices of Don Gabriel. In Dennis Tedlock \& Bruce Mannheim (eds.), The dialogic emergence of culture, 97-147. Urbana: University of Illinois Press.

(2001). Mock Spanish, covert racism, and the (leaky) boundary between public and private spheres. In Susan Gal \& Kathryn A. Woolard (eds.), Languages and publics: The making of authority, 83-102. Manchester: St. Jerome.

Hvalkof, Søren, \& Hanne Veber (2005). Ashéninka del Gran Pajonal. Guía Etnográfica de la Alta Amazonía 5:75-279.

Irvine, Judith T., \& Susan Gal (2000). Language ideology and linguistic differentiation. In Paul Kroskrity (ed.), Regimes of language: Ideologies, polities, and identities, 35-83. Santa Fe, NM: School of American Research Press.

Izquierdo, Carolina, \& Allen W. Johnson (2007). Desire, envy and punishment: A Matsigenka emotion schema in illness narratives and folk stories. Culture, Medicine and Psychiatry 31:419-44.

Johnson, Allen W. (1999). The political unconscious: Stories and politics in two South American cultures. In Stanley A. Renshon \& John Duckitt (eds.), Political psychology: Cultural and crosscultural foundations, 159-81. New York: New York University Press.

- (2003). Families of the forest: The Matsigenka Indians of the Peruvian Amazon. Berkeley: University of California Press.

Johnson, Orna (1978). Interpersonal relations and domestic authority among the Machiguenga of the Peruvian Amazon. New York: Columbia University dissertation.

Killick, Evan (2007). Autonomy and leadership: Political formations among the Ashéninka of Peruvian Amazonia. Ethnos 72:461-82.

- (2008). Creating community: Land titling, education, and settlement formation among the Ashéninka of Peruvian Amazonia. Journal of Latin American and Caribbean Anthropology 13:22-47.

Kulick, Don (1992). Language shift and cultural reproduction: Socialization, self, and syncretism in a Papua New Guinean village. Cambridge: Cambridge University Press.

Landes, Joan B. (1998). Feminism: The public and the private. London: Oxford University Press.

Mannheim, Bruce (1998). A nation surrounded. In Elizabeth Hill Boone \& Tom Cummins (eds.), Native traditions in the postconquest world, 383-420. Washington, DC: Dumbarton Oaks.

Myers, Fred R., \& Donald Lawrence Brenneis (1984). Introduction: Language and politics in the Pacific. In Donald Lawrence Brenneis \& Fred R. Myers (eds.), Dangerous words: Language and politics in the Pacific, 1-29. New York: New York University Press.

Renard-Casevitz, France-Marie (1993). Guerriers du sel, sauniers de la paix. L'Homme 33:25-43.

Rosaldo, Michelle Zimbalist (1974). Woman, culture, and society: A theoretical overview. In Michelle Zimbalist Rosaldo \& Louise Lamphere (eds.), Woman, culture, and society, 17-42. Stanford, CA: Stanford University press.

Rosengren, Dan (1987). In the eyes of the beholder: Leadership and the social construction of power and dominance among the Matsigenka of the Peruvian Amazon. Göteborg: Göteborg Etnografiska Museum. 


\section{PUBLIC DISCOURSE AND COMMUNITY FORMATION}

(2000). The delicacy of community: On kisagantsi in Matsigenka narrative discourse. In Joanna Overing \& Alan Passes (eds.), The anthropology of love and anger: The aesthetics of conviviality in Native Amazonia, 221-34. London: Routledge.

(2003). The collective self and the ethnopolitical movement: 'Rhizomes' and 'Taproots' in the Amazon. Identities 10:221-40.

(2004). Los Matsigenka. In Fernando Santos-Granero \& Frederica Barclay (eds.), Guía Etnográfica de la Alta Amazonía, vol. IV. Lima: Smithsonian Tropical Research Institute/IFEA.

Sala i Vila, Núria (1998). Cusco y su proyección en el Oriente Amazónico, 1800-1929. In Pilar García Jordán (ed.), Fronteras, colonización y mano de obra indígena en la Amazonía Andina (Siglos XIX-XX), 401-535. Lima: Pontificia Universidad Católica del Perú and Universitat de Barcelona.

Silverstein, Michael (2003). Indexical order and the dialectics of sociolinguistic life. Language and Communication 23:193-229.

(2005). Axes of evals: Token versus type interdiscursivity. Journal of Linguistic Anthropology $15: 6-22$.

Steward, Julian H. (1955). Theory of culture change. Urbana: University of Illinois Press.

Varese, Stefano (2002). Salt of the mountain: Campa Asháninka history and resistance in the Peruvian jungle. Norman: University of Oklahoma Press.

Veber, Hanne (1998). The salt of the Montaña: Interpreting indigenous activism in the rain forest. $\mathrm{Cul}$ tural Anthropology 13:382-413.

Warner, Michael (1990). The letters of the republic: Publication and the public sphere in eighteenthcentury America. Cambridge, MA: Harvard University Press.

(1992). The mass public and the mass subject. In Craig J. Calhoun (ed.), Habermas and the public sphere, 377-401. Cambridge, MA: MIT Press.

(2005). Publics and counterpublics. New York: Zone Books.

Woolard, Kathryn A. (1989). Sentences in the language prison: The rhetorical structuring of an American language policy debate. American Ethnologist 16:268-78.

(Received 29 June 2014; revision received 18 November 2014; accepted 9 March 2015; final revision received 4 May 2015) 